\title{
Renting a Home: Your Rental Agreement ${ }^{1}$
}

Mary N. Harrison ${ }^{2}$

Florida has laws for both the resident and landlord.

\section{RENTAL AGREEMENT}

A. The lease or rental agreement you sign tells what you are to do and what the landlord must do.

B. Make sure you are given a copy of your signed lease or rental agreement. Keep it in a safe place. You may need to refer to it at a later date.

C. Find out if you must pay for utilities and garbage collection or if they are included in the rent.

\section{UNIT INSPECTION}

A. Before you sign a lease or move in, you should walk through the residence with the landlord and write down the condition of the unit.

B. Inspect everything including the appliances, walls, windows, floors, etc.

C. You and the landlord should sign this list and both keep a copy. After moving in you are responsible for the condition of the property.

D. If you take good care of your home you will get better service and feel happier in your home.

\section{RENT}

A. The lease or rental agreement tells you when the rent is due.

B. Make sure you pay the rent on or before the "DUE DATE" so that you will not have to pay a late fee.

C. Some (but not all) landlords allow a few extra days as a grace period before charging a late fee. By law the rent is due on the stated date, NOT at the end of the grace period. Grace periods are for emergencies only.

D. Always get a receipt if you pay your rent with cash. Keep this receipt in the same place as your rental agreement. If you pay your rent by check, your cancelled check is a valid receipt showing your payment.

E. Late rent payment may affect your credit rating. A bad credit rating can make it harder to get credit, buy a car or a home or rent another place.

1. This document is FCS5231-02, one of a series of the Department of Family, Youth and Community Sciences, Florida Cooperative Extension Service, Institute of Food and Agriculture Sciences, University of Florida. Publication: May 2002. Reviewed: December 2005. Please visit the EDIS Web site at http://edis.ifas.ufl.edu.

2. Mary N. Harrison, professor, Department of Family, Youth and Community Sciences, Cooperative Extension Service, Institute of Food and Agricultural Sciences, University of Florida, Gainesville, 32611. 


\section{SECURITY DEPOSIT}

A. You will probably be required to pay a security deposit when you rent your home.

B. You are responsible for taking care of the property. If you do, your deposit will be returned after you move. If the residence is damaged during your lease, your deposit will be used by the landlord to repair the damage. You may or may not receive any security deposit back if the property is damaged.

C. If there is a damage charge, the landlord must notify you in writing within 15 days of moving.

D. If you object to the damage charge you must notify the landlord in writing within 15 days after receiving notice.

E. You and your landlord should walk through the residence with your inspection list when you move out. That helps you to identify any damage you may have to pay for.

\section{COMMUNICATION}

A. You and your landlord each have rights and responsibilities.

B. All requests and responses should be in writing. Make sure you keep a copy. Hand carry or send by Certified Mail, request a return receipt (record of delivery) and keep it. Put this with the rent payments and lease agreement.

\section{THE LANDLORD’S OBLIGATION}

A. The landlord must comply with the local building, housing and health codes. The roof, windows, screens, doors, floors, steps and outside walls must be kept in good repair.

B. Unless other agreements are made in writing, the landlord must provide:

1. Lock and key.

2. A unit that meets all local code requirements.

3. A copy of the lease or rental agreement.

\section{THE RESIDENT'S OBLIGATION}

A. Pay rent on or before the due date.

B. Pay for utilities and garbage collection if required.

C. Clean your home regularly.

D. Keep the outside areas safe and litter free.

E. Remove garbage from dwelling in a clean and sanitary manner.

F. Keep all plumbing clean and in good repair. Do not put grease down the kitchen sink or sanitary items down the toilet. Try to manage small problems yourself. Report large problems.

G. Use and operate all electrical, plumbing, heating, ventilating and other appliances carefully. 


\section{ENDING RENTAL AGREEMENT AND EVICTIONS}

A. If your residence is not kept up to building, housing and health codes you may notify the landlord in writing. If the landlord agrees, you can make the necessary repairs and get reimbursed. (If your home is not brought up to code after the landlord has been notified, you may break the lease.)

B. If you do not pay the rent the landlord will send a written notice letting you know that you will be evicted unless the rent is paid.

C. If you violate the terms of your lease (disruptive parties, damage the building, etc.), the landlord will notify you in writing, giving you seven days to correct the situation or the lease/rental agreement will be cancelled.

D. If you plan to move when the lease expires you must notify the landlord before the lease ends.

1. A 1-year lease requires a 60-day notice.

2. A 3-month lease requires a 30-day notice.

E. If the landlord plans to not renew a lease, he/she must notify you in writing.

1. A 1-year lease requires 60 -day notice

2. A 3-month lease requires 30-day notice. 


\section{PROBLEMS OFTEN FOUND IN RENTAL UNITS}

Always inspect an apartment or house before signing a lease and moving in. If there are problems make sure they are corrected before moving in or that the problems are listed on your inspection list so that you will not be held responsible for them.

Here are some of the more frequently found problems. Make sure:

- all doors and windows lock securely.

- there is no broken or cracked window glass.

- there is no leaky plumbing (dripping fixtures cause stains and add costs to you water bill).

- there are no broken or missing floor, bathroom, or sill window tiles.

- there are unbroken screens on all windows and on all sliding glass doors where applicable.

- there are working smoke detectors on each level of the house.

- the electrical panel is labeled.

- there is an ABC fire extinguisher installed near the kitchen.

- there are no roof leaks (water marks on the ceiling are a good indication that the roof is leaking).

- there are no signs of roaches and/or mice.

- all electrical outlets and switches are working and none are broken or cracked.

- the gas water heater and other appliances are properly vented.

- roofs are clean of all trash and debris (i.e., leaves, branches, pine needles).

- the house number is on the house and can be seen from the street. (This is important in case of a 911 emergency).

- $\quad$ there are no broken hand rails or stairs (any stairs with more than three steps needs a hand rail).

- $\quad$ all interior and exterior light bulbs are covered with a fixture/globe.

- electrical outlets located within six feet of a water source are GFCI (ground fault circuit interrupter receptacles, a safety feature).

- all windows and doors close to form a reasonably tight weather seal.

- the yard is clean and mowed.

- all doors have door stops.

- there is no peeling or chipping paint - inside and outside.

- there are no holes in the walls or doors.

- the unit is accessible if you are disabled.

The response you receive from the landlord about fixing items will be a good indication of how the landlord intends to make repairs after you have signed a lease or moved in. 